\title{
Overcoming the UCB HSCs -Derived NK cells Dysfunction through Harnessing RAS/MAPK, IGF-1R and TGF- $\beta$ Signaling Pathways
}

Alireza Shokouhifar ${ }^{1,2,3}$, Gholamreza Anani Sarab ${ }^{2 *}$, Mahboubeh Yazdanifar ${ }^{4}$, Mohammad Fereidouni ${ }^{2}$, Masoumeh Nouri ${ }^{5}$ and Marzieh Ebrahimi ${ }^{4^{*}}$ (B)

\begin{abstract}
Background: The natural killer (NK) cells differentiated from umbilical cord blood (UCB) hematopoietic stem cells (HSCs) may be more suitable for cell-based immunotherapy compared to the NK cells from adult donors. This is due to the possibility to choose alloreactive donors and potentially more robust in vivo expansion. However, the cytotoxicity of UCB-HSC-derived NK cells against cancer cells might be suboptimal. To overcome this obstacle, we attempted to generate NK cells with potent antitumor activity by targeting RAS/MAPK, IGF-1R and TGF- $\beta$ signaling pathways using IL-15, IGF-1 and SIS3 respectively.
\end{abstract}

Methods: The CD34 + cells were isolated from human UCB mononuclear cells through magnetic activation cell sorting (MACS) with purity of ( $\geq 90 \%)$ and were subjected to differentiate into NK cells. After 21 days of induction with SFTG36 (SCF, FLt-3L, TPO, GM-CSF, IL-3 and IL-6), IS721 (IGF-1, SIS3, IL-7 and IL-21) and IL-15/Hsp70 media, NK cells phenotypes were studied and their cytotoxicity against K562 human erythroleukemia cells and SKOV3 ovarian carcinoma cells was analyzed.

Results: The NK cells induced in SFTG36/IS721 medium were selected for activation due to their higher expression of CD56 + 16 + CD3 - (93.23\% \pm 0.75$)$ and mean fluorescence intensity (MFI) of NKG2D + (168.66 \pm 20.00$)$ and also a higher fold expansion potential (11.893 \pm 1.712$)$ compared to the other groups. These cells once activated with IL-15, demonstrated a higher cytotoxicity against K562 ( $\geq 90 \%$; $P \leq 0.001)$ and SKOV3 tumor cells $(\geq 65 \% ; P \leq 0.001)$ compared to IL-15/Hsp70-activated NK cells.

Conclusions: The differentiation of ex vivo expanded CD34 + cells through manipulation of RAS/MAPK, IGF-1R and TGF- $\beta$ signaling pathways is an efficient approach for generating functional NK cells that can be used for cancer immunotherapy.

Keywords: Umbilical cord blood, Natural killer cells, Differentiation, Cytotoxicity, Cancer immunotherapy

*Correspondence: ghansa@yahoo.co; mmd643@bums.ac.ir; mebrahimi@royaninstitute.org

${ }^{2}$ Cellular \& Molecular Research Center, Birjand University of Medical Sciences, Birjand, Iran

${ }^{4}$ Stem Cell Transplantation and Regenerative Medicine, Department of Pediatrics, Stanford University School of Medicine, Palo Alto, CA, USA Full list of author information is available at the end of the article

\section{Background}

Immune cell-based therapy aims at harnessing the patient's own immune system to fight cancer and to obtain long-term responses in patients $[1,2]$. Among various components of the immune system, natural killer (NK) cells of the innate immune system lymphocytes are able to kill tumor and virus-infected cells without prior sensitization to antigens [3, 4]. For this, many efforts have

c) The Author(s) 2021. This article is licensed under a Creative Commons Attribution 4.0 International License, which permits use, sharing, adaptation, distribution and reproduction in any medium or format, as long as you give appropriate credit to the original author(s) and the source, provide a link to the Creative Commons licence, and indicate if changes were made. The images or other third party material in this article are included in the article's Creative Commons licence, unless indicated otherwise in a credit line to the material. If material is not included in the article's Creative Commons licence and your intended use is not permitted by statutory regulation or exceeds the permitted use, you will need to obtain permission directly from the copyright holder. To view a copy of this licence, visit http://creativeco mmons.org/licenses/by/4.0/. The Creative Commons Public Domain Dedication waiver (http://creativecommons.org/publicdomain/ zero/1.0/) applies to the data made available in this article, unless otherwise stated in a credit line to the data. 
been made to apply the NK cells derived from peripheral blood to adoptive therapy of solid and hematopoietic cancers $[1,5]$. However, this approach has encountered several drawbacks including: insufficient cell number, limited donors, lower response to stimulants, decreased expansion potential and increased dysfunctionality. To address these limitations, other sources for NK cells such as bone marrow, embryonic cells, induced pluripotent and umbilical cord blood stem cells (UCB-HSC) have been tested [6-10].

UCB-HSCs have significant advantages over other sources of NK cells including availability, easy expansion and differentiation into other immune cells, containing numerous NK cell progenitors, fast engraftment and immune reconstitution, less stringent requirements for HLA matching and lower risk of graft versus host disease (GvHD); hence, they can be used to generate NK cells [1, $6,11]$. Various methods have been developed to generate NK cells with high purity (>90\%) from UCB-HSCs [610]. Although several clinical trials have been performed; it is still difficult to obtain functional NK cells by ex vivo cultivation of UCB-HSCs $[6,7]$. The dysfunctional NK cell phenotypes are often determined as down regulation of specific surface activating receptors including NKG2D, CD16 and NCRs (NKp30, NKp44 and NKp46) [12-14] and up regulation of the inhibitory receptors including NKG2A, Tim3 and PD-1 [13, 15-18] on NK cells in tumors and chronic infections [13].

RAS/MAPK, PI3K/AKT, JAK/STAT and TGF- $\beta$ are among the most prominent signaling pathways involved in switching between NK activation and inhibition [13, 14, 16]. PI3K signaling pathway is activated by the activating receptors signals such as $2 \mathrm{~B} 4$ and KIR receptors and plays a key role in NK cells activation. Activate MEK-ERK pathway, which is a key signaling pathway for actin reorganization and cell polarization. PI3K signaling pathway is involved in the cytotoxicity and migration of NK cells by controlling actin remodeling, polarization, and even granule exocytosis [12-14]. NK cells also use PI3K-AKT-mTOR pathway to modulate their development, differentiation, and activation. This signaling pathway in NK cells can be stimulated by JAK-STAT pathway and the related cytokines. The signaling pathways have the potential to affect the cytokine priming for NK cell activation by stimulation with common gamma chain cytokines (IL-2, -15, -21) or IL-12 and IL-18 [13, 15]. TGF- $\beta$ is a negative-regulatory cytokine on NK cells antitumor function which can be particularly effective in negatively regulating IFN- $\gamma$ production and expression of NKG2D and NKp30 activating receptors. TGF- $\beta$ also alters the surface expression of chemokine receptors such as CXCR3, CXCR4, CX3CR1 and has negative effects on the migration of NK cells to the tumor site [13, 16-18].
Therefore, targeting these pathways may be an effective strategy for producing active and functional NK cells. In the present study to promote NK differentiation, RAS/ MAPK pathway was activated using IGF-1 [19], JAK/ STAT signaling pathway was induced using IL-21 [20, 21 ] and TGF- $\beta$ signaling pathway was blocked using SIS3 [22-24]. Moreover, IL-7 was used as the NK cells differentiation and maturation factor $[25,26]$.

The aim of the present study was to differentiated to functional NK cells from UCB-CD34+ through manipulation of RAS/MAPK, PI3K/AKT, JAK/STAT and TGF- $\beta$ as the critical activation and inhibition signaling pathways of NK cells starting from the early differentiation phase (Fig. 1). Another goal of this study was achieving the desirable NK cell quantity during the differentiation process.

\section{Methods \\ Cell lines}

K562 and SKOV3 cell lines (Royan Institute Cell Bank, Tehran, Iran) were cultured in RPMI 1640 (Gibco, USA) containing $50 \mathrm{U} / \mathrm{ml}$ penicillin, $50 \mathrm{mg} / \mathrm{ml}$ streptomycin and $10 \% \mathrm{FBS}$ and incubated at $37^{\circ} \mathrm{C}$ in $5 \% \mathrm{CO}_{2}$.

\section{Isolation and expansion of $\mathrm{CD} 34$ + cells}

MNCs were harvested from UCB using Ficoll-Hypaque density gradient centrifugation and then $\mathrm{CD} 34+$ cells were isolated using magnetic bead selection (Miltenyi Biotech, USA). The purity of the isolated cells was $92 \% \pm 2.30$ (Additional file 1: Figure S1) which was confirmed by flowcytometry and specific antibody against CD34.

CD34 + cells were seeded at $7 \times 10^{5}$ cells per well in 6-well plates (TPP, Switzerland) in Advanced RPMI 1640 medium (Gibco, USA) with penicillin/streptomycin (100 $\mathrm{U} / \mathrm{ml}$ ) and cytokines cocktail (SCF, TPO, FLt3-L, IL-3, IL-6, and GM-CSF) (all from R\&D Systems, USA) at the expansion phase of cultures (Table 1). Every 2-3 days, half of the media was replaced with fresh media for 7 days. Fold expansion was calculated by dividing the absolute output number of the expanded cells after each phase of culture by the respective number on the day 0 .

\section{Differentiation of CD34 + cells to NK cells and their activation}

To differentiate CD34+ cells into NK cells, the expanded cells at the previous step were seeded at the density of $7 \times 10^{5}$ cells per well in 6 -well plates in the NK cell differentiation medium composed of SCF, TPO, rhIGF-1 (Royan Biotech CO, Iran), rhIL7, rhIL21 and SIS3 (Smad3 inhibitor) (Calbiochem, USA). Half of the medium was changed every 2-3 days for about 10 days (from day 7 to 17 of culture). 


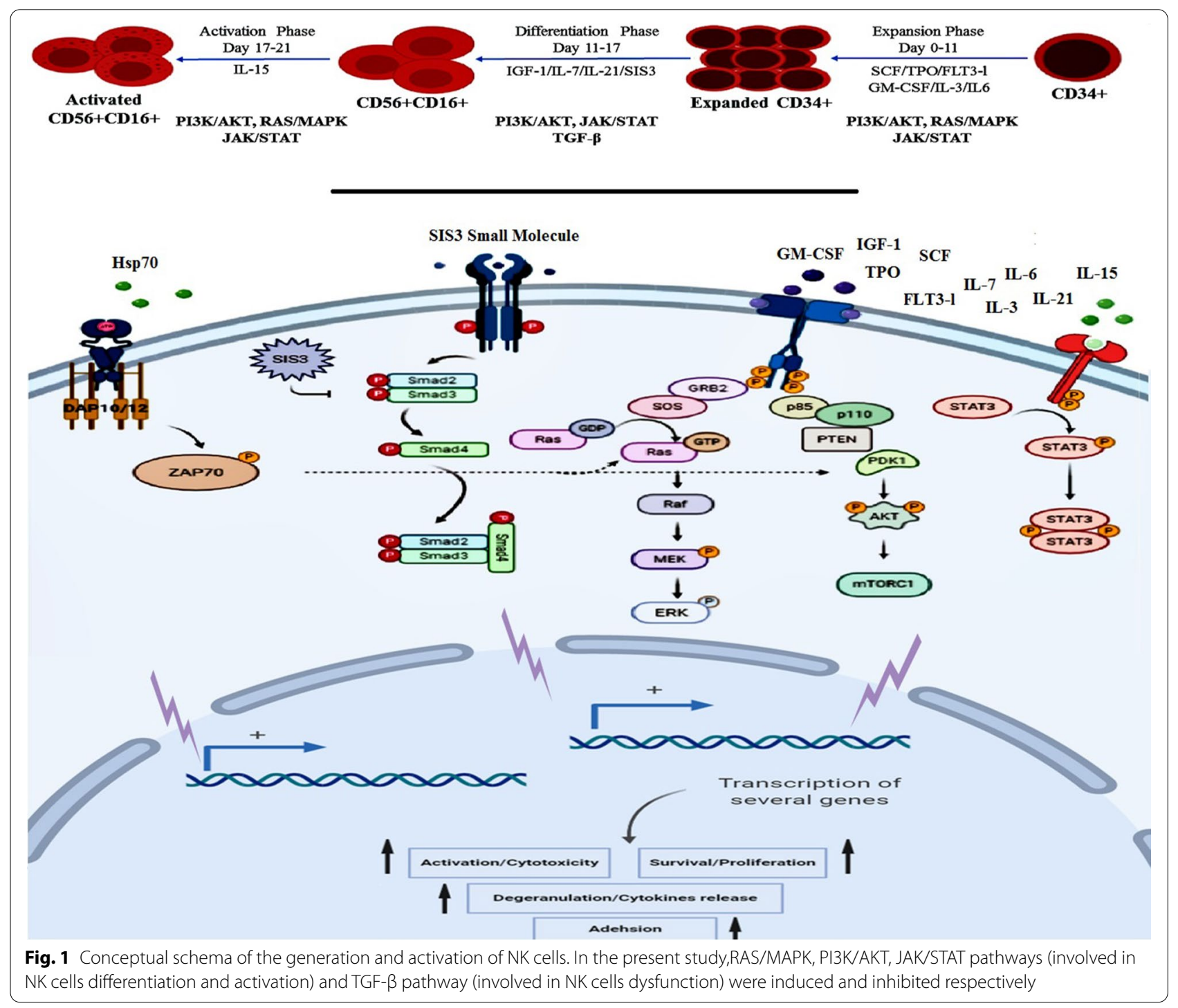

To activate the differentiated NK cells, an activation medium containing SCF, TPO, rhIGF-1, rhIL7, rhIL21, SIS3 (Smad3 inhibitor), rhIL15 and rhHsp70 (according to our previous study [27]) was used. The details of culture media used in each phase are listed in table 1.

The fold expand of cells was calculated and their immunophenotype was assessed using specific antibody for each step and by flow cytometry.

\section{Colony forming unit assay (CFU assay)}

The CFU assay was performed using the commercially available methylcellulose medium (MethoCult H4435 Enriched; Stem cell Technologies, Vancouver, BC, Canada). This medium supports the clonal progeny of a single-cell to differentiate and grow in distinct colonies including BFU-E (burst-forming unit-erythroid), CFU-E (colony-forming unit-erythroid), CFU-GEMM (colony-forming unit-granulocyte, erythroid, macrophage, megakaryocyte) and CFU-GM (colony-forming unit-granulocyte, macrophage). $1 \times 10^{3} \mathrm{CD} 34+$ cells were added to $2 \mathrm{ml}$ MethoCult $\mathrm{H} 4435$ medium and vortexed vigorously until the cells were well suspended and $1 \mathrm{ml}$ of the cell suspension was subsequently plated in a 12-well plate at a final density of $5 \times 10^{2}$ cells/well. Cells were finally incubated at $37{ }^{\circ} \mathrm{C}$ in $5 \% \mathrm{CO}_{2}$ for $12-14$ days.

\section{Wright-Giemsa staining}

Morphological characteristics of the expanded CD34+ cells were detected by Wright-Giemsa staining on the day 14. Briefly smears of cells were stained with Wright-Giemsa solution for $25 \mathrm{~min}$, rinsed with distilled water and air dried and cells morphology was finally studied by light microscopy. 
Table 1 Culture media in different phases of NK generation

\begin{tabular}{|c|c|c|c|}
\hline Phase & Cell culture medium & $\begin{array}{l}\text { Concentration } \\
(\mathrm{ng} / \mathrm{ml})\end{array}$ & $\begin{array}{l}\text { Exposure } \\
\text { time (day) }\end{array}$ \\
\hline \multirow[t]{6}{*}{ Expansion } & SCF & 50 & 7 \\
\hline & TPO & 50 & \\
\hline & FLt3-L & 50 & \\
\hline & GM-CSF & 50 & \\
\hline & rhlL-3 & 25 & \\
\hline & rhlL-6 & 25 & \\
\hline \multirow[t]{6}{*}{ Differentiation } & SCF & 25 & 10 \\
\hline & TPO & 25 & \\
\hline & rhlGF-1 & 50 & \\
\hline & rhlL-7 & 25 & \\
\hline & rhlL-21 & 25 & \\
\hline & SIS3 (Smad3 inhibitor) & 0.125 & \\
\hline \multirow[t]{8}{*}{ Activation } & SCF & 2.5 & 4 \\
\hline & TPO & 2.5 & \\
\hline & rhlGF-1 & 5 & \\
\hline & rhlL-7 & 10 & \\
\hline & rhlL-15 & 50 & \\
\hline & rhlL-21 & 10 & \\
\hline & SIS3 (Smad3 inhibitor) & 0.125 & \\
\hline & rhHsp70 & 2000 & \\
\hline
\end{tabular}

SFT (SCF/ FLt3-L/TPO), SFT36G (SCF/ FLt3-L/TPO/LL-3/LL-6/GM-CSF)

17 (IGF-1/IL-7), 121 (IGF-1/LL-21), 1721 (IGF-1//L-7/LL-21), IS721 (IGF-1/SIS3/ IL-7/ IL-21)

\section{Flowcytometry analysis}

Single cells at each step were labeled with specific antibodies including anti-hCD45-FITC, anti-hCD34-PE, anti-hCD3-FITC, anti-hCD56/CD16-PE, anti-hNKG2DPE, anti-hNKG2A-Alexa Fluor488, anti-hNKp30-PE and anti-hNKp44-Alexa Fluor488 (all from BD Biosciences, USA) as multicolor staining and then analyzed using BD FACS Calibure. The data was further analyzed using FlowJo software Ver.10.6.1. The percentage of CD34 + cells was assessed in expansion phase while the percentage of CD3-CD56+/CD16+cells was tested in the differentiation phase. In the activation phase, the expression percentage of CD3-CD56+/CD16+, NKG2D +, NKG2A +, NKp30+ and NKp44+ markers on NK cells were assessed.

Quantitative real time reverse transcription PCR (Q-RTPCR) RNAs were isolated using Gene All Hybrid-R kit (Biotech, Korea). Spectrophotometric methods were used to assess the quality and quantity of RNAs. cDNA was synthesized from $1 \mu \mathrm{g}$ of total RNA with RT-for-PCR kit (Takara Bio, Inc., Otsu, Japan) according to the manufacturer's instructions. The sequence of primers used for measuring gene expression is listed in Additional file 4: Table S1. $\beta 2$-microglubolin RNA levels was used as an internal control for all experiments. Amplification was performed for 1 cycle of a sequential incubation at $50{ }^{\circ} \mathrm{C}$ for $2 \mathrm{~min}, 95{ }^{\circ} \mathrm{C}$ for $10 \mathrm{~min}$, and subsequent 40 cycles of a consecutive incubations at $94{ }^{\circ} \mathrm{C}$ for $1 \mathrm{~min}$, at $60{ }^{\circ} \mathrm{C}$ for $1 \mathrm{~min}$ and at $72{ }^{\circ} \mathrm{C}$ for $1.5 \mathrm{~min}$. The individual gene expression value was calculated after normalization to $\beta 2$-microglubolin gene. Quantitation of the mRNAs was determined by the comparative cycle threshold (CT) method. The relative change in mRNA concentration for each test sample was then determined from the difference between the calibrator CT and the $\mathrm{CT}$ of each test sample. Each sample was run in triplicate and the relative expression of the target genes was determined using $2^{-\Delta \Delta \mathrm{Ct}}$ equation.

Perforin, IFN- $\gamma$, Granzyme A and B mRNA levels were evaluated by quantitative real-time RT-PCR (SYBR Green assay) using a Rotor-Gene 6000 (Corbett Life Sciences, Sydney, Australia) Sequence Detector.

\section{Cytotoxicity assay}

K562 (chronic myeloid leukemia) and SKOV3 (malignant ovarian cancer line) cells were inactivated with Mitomycin C $(10 \mu \mathrm{g} / \mathrm{ml})$ to inhibit their proliferation, then they were labeled with Calcein AM for $45 \mathrm{~min}$ incubation at $37{ }^{\circ} \mathrm{C}$ in $5 \% \mathrm{CO}_{2}$. The labeled cells were washed with PBS, re-suspended in RPMI with 10\% FBS, and plated in 6 -well plates at $3 \times 10^{5}$ cells/well in triplicate as target cells. NK cells as the effector cells were co-cultured with K562 cells at effector:target (E:T) ratios of 3:1 and 5:1 followed by incubation for 24, 48 and $72 \mathrm{~h}$ at $37{ }^{\circ} \mathrm{C}$ in $5 \% \mathrm{CO}_{2}$. For SKOV3 cells we used 3:1 E:T ratio and incubated for $48 \mathrm{~h}$ at $37{ }^{\circ} \mathrm{C}$ in $5 \% \mathrm{CO}_{2}$. Cytotoxicity level was evaluated by calcein/propidium iodide (PI) staining and flowcytometry. The control groups were the tumor cells cultivated in the same medium, which were not treated with NK cells.

\section{Statistical analysis}

The statistical analysis was performed using Graph pad Prism Ver.8 and the data was presented as the means $\pm S D$. Statistical differences were determined using paired Student's t tests or two-tailed Student's t tests when comparing two groups and one-way or twoway ANOVA analysis when comparing more than two groups. Differences were considered statistically significant at $\mathrm{P}<0.05$. Data from three different biological replicates was collected. 


\section{Results}

\section{SFTG36 as the proper cytokine combination} for the expansion of UCB hematopoietic CD34 + cells

As mentioned in the method section, we differentiated and activated NK cells in a three-step protocol; expansion, differentiation and activation phases. As the first step, we sought to determine the best cocktail of cytokines for CD34 + cells expansion. Different combination of cytokines was selected based on literature and divided into two groups: SFTG36 medium containing SCF/FLt3-L/TPO/GM-CSF/IL-3/IL-6 and SFT medium containing SCF/FLt3-L/TPO. Our results indicated that a higher number with larger colonies of CFU-BFU-E, CFU-GM and CFU-GEMM was formed in CD34 + cells treated with SFTG36 (P<0.0001) (Fig. 2A, B). The obtained results were also confirmed morphologically through Wright-Giemsa staining (more lymphoid progenitors) (Fig. 2A). The fold expansion was 53.72 \pm 1.86 fold in SFTG36 and 8.00 \pm 3.98 fold in SFT media after 7 days of cultivation (Fig. 2C). The cell viability in both groups was higher than 95\% (Fig. 2D). Moreover, $79.55 \pm 18.2 \%$ and $42.33 \pm 19.05 \%$ of cells in SFTG36 was CD $45+$ and CD $45+/ C D 34+$ cells, that was higher compared to SFT group (19.52 $\pm 4.276 \%$ CD $45+$ and

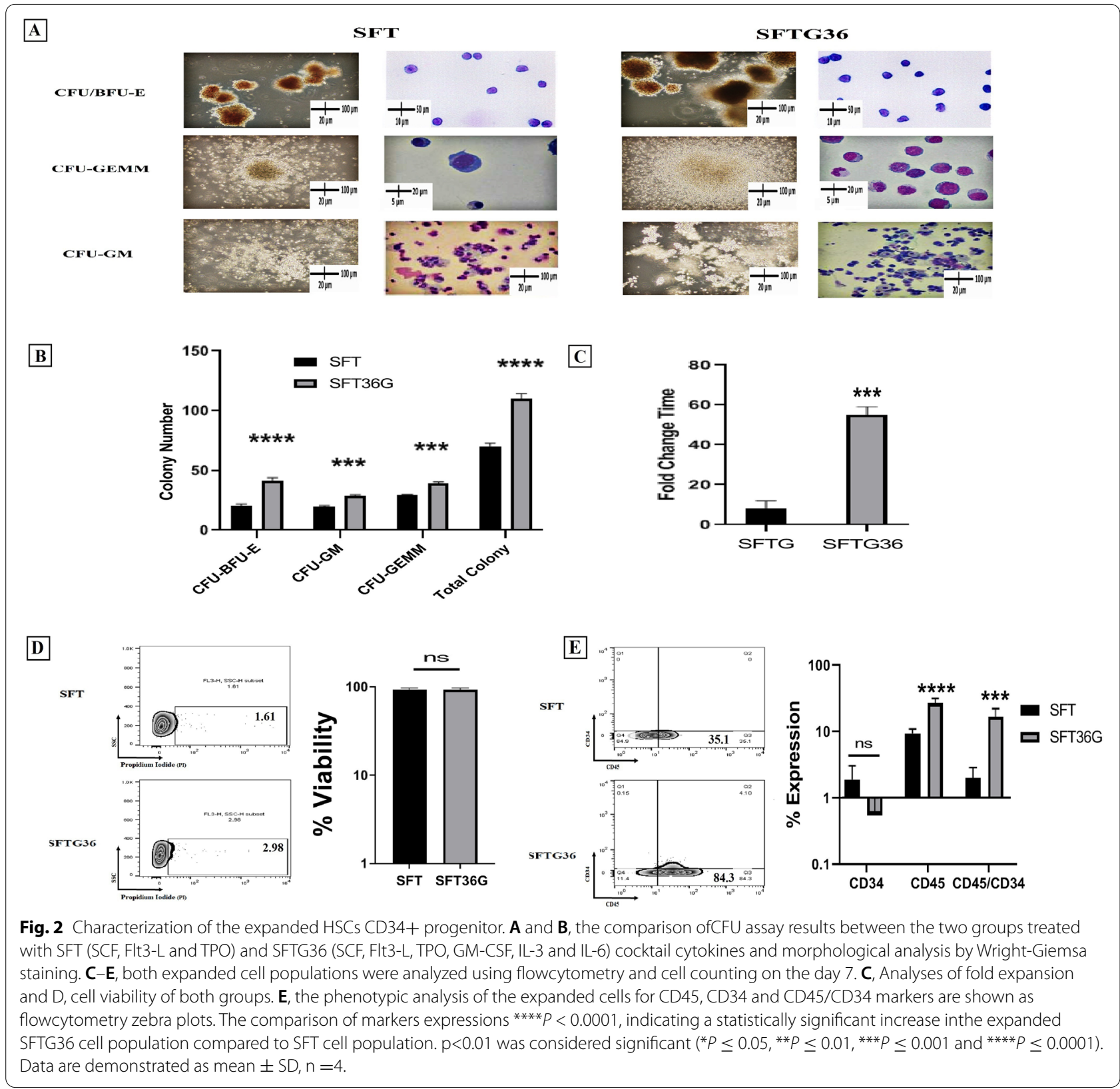


$2.5 \pm 1.51 \% \mathrm{CD} 45+/ \mathrm{CD} 34+$ ) (Fig. 2E). Therefore, based on the above data, the cells expanded in SFTG36 medium were considered for NK differentiation.

\section{The significant roles of Smad3 blockade and IGF-1 in NK cell differentiation}

As mentioned earlier, different signaling pathways affect NK cell differentiation and the efficacy of the differentiation procedure. In the present study, we used IGF-1 to activate RAS/MAPK pathway, IL-21 to induce JAK/STAT signaling pathway, SIS3 to block TGF- $\beta$ signaling pathway, and IL-7 as NK cells differentiation and maturation factor. Therefore, the expanded HSCs were cultivated in I721 medium containing IL-7/IL-21 + IGF-1 and IS721 medium containing IL-7/IL-21 + IGF-1 + SIS3.
Our results indicated a low percentage of $\mathrm{T}$ cells $(\mathrm{CD} 3+)$ and NKT cells $(\mathrm{CD} 3+/ \mathrm{CD} 56+\mathrm{CD} 16+)$ in all tested groups $(<1 \%$ and $<2 \%$, respectively) following 17 days of cultivation (Additional file 2: Figure S2). Both differentiation media, represented the highest percentage of CD $56+16+\mathrm{CD} 3$ - cells $(92.7 \% \pm 1.45$ in I721 and $93.23 \% \pm 0.75$ in IS721 group) (Fig. 3A, B). the expression of NKG2D activating marker also demonstrated a significant increase in MFI $(168.00 \pm 20.88$ in I721 and $168.66 \pm 20.08$ in IS721 group) (Fig. 3A, C; Additional file 2: Figure S2). The fold expansion of the differentiated cells was assed and the cells treated with I721 $(8.093 \pm 1.205)$ and IS721 demonstrated a more significant expansion $(11.893 \pm 1.712)$ compared to the other group (Fig. 3D). Finally, the cells differentiated in

$\mathbf{A}$
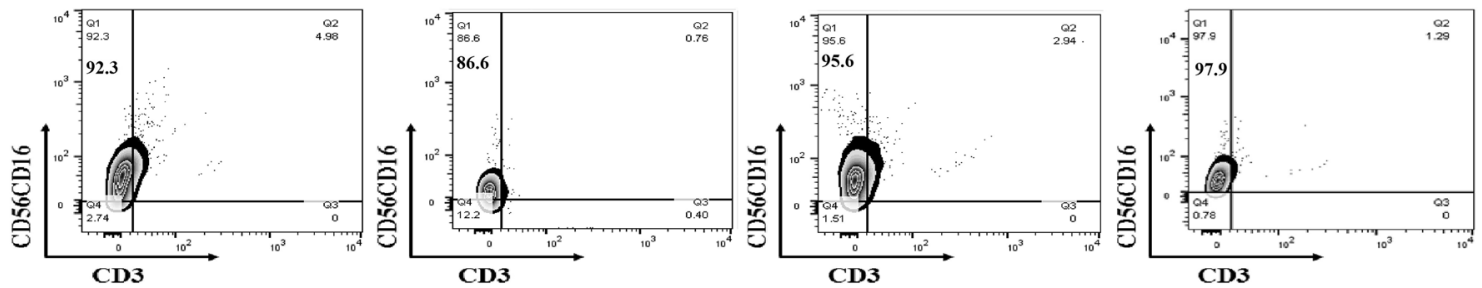

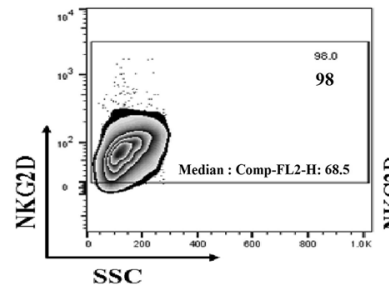

IL-7

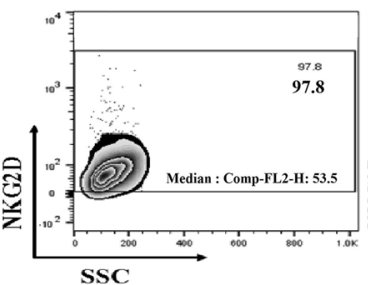

IL-21

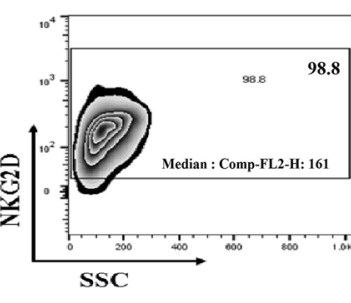

IL-7+IL-21

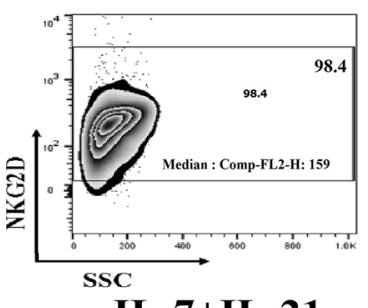

IL-7+IL-21 SIS3
B

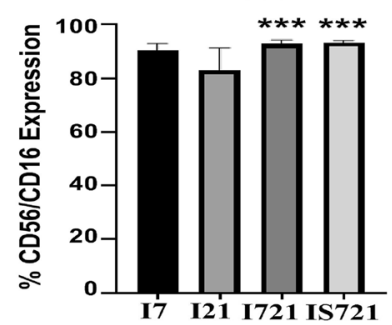

$\mathbf{C}$

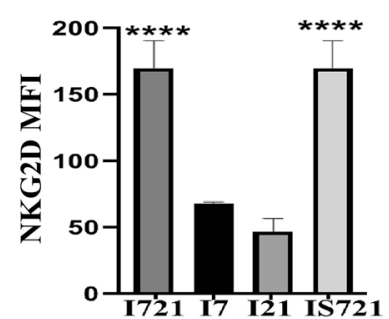

D

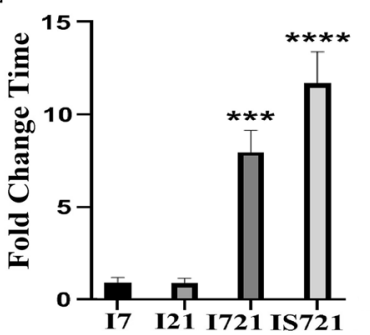

Fig. 3 Comparison of characteristics of differentiated NK cells. $\mathbf{A}$ and $\mathbf{B}$ assessment of CD56/CD16and CD3 markers expression among all 4 groups (IL-7+ IGF-1, IL-21+IGF-1, IL7+IL-21 + IGF-1 and IL-7+IL-21+SIS3+IGF-1) showed a significant expression difference in the groups IL-7+IL-21 + IGF-1 $(P<0.01)$ and IL-7+IL-21+ IGF-1+SIS3 $(P<0.01)$. C, these 2 groups also demonstrated significant difference in the expression of NKG2D compared to the other groups. D, the expansion potential analysis showed that IL-7+IL-21+ IGF-1+SIS3 group had the highest level of Fold expansion among all groups $(P<0.05)$. It should be noted that all expressions were assessed in the viable cells $(>90 \% \pm 3.00)$. $P<0.01$ was consideredsignificant ${ }^{*} P \leq$ $0.05,{ }^{* *} P \leq 0.01,{ }^{* * *} P \leq 0.001$ and $\left.{ }^{* * *} P \leq 0.0001\right)$. Data is demonstrated as mean $\pm \mathrm{SD}, \mathrm{n}=3$. 
IS721 medium based on phenotyping and proliferative potential were subjected for NK activation.

\section{Evaluation of the induced NK cell function}

To evaluate the function of the differentiated NK cells we entered them into the activation phase and they were incubated with IL-15 and IL-15/Hsp70, for an additional four days. The potential of the activated NK cells was tested through Immunophenotyping analysis. Both activation groups could increase the percentage of NKG2D, NKG2A and NKp30 positive cells $(\mathrm{P}>0.05)$ (Fig. 4A-left).
However, MFI of NKG2D $(61.12 \pm 17.62, P<0.0001)$ and NKp30 $(48.17 \pm 0.83, P<0.0001)$ were higher in IL-15/ Hsp70 -treated group compared to IL-15 treated group (Fig. 4A-right). The expression of perforin $(0.317 \pm 0.095$ fold, $P<0.0001)$, IFN- $\gamma(0.280 \pm 0.046$ fold, $P<0.01)$, granzyme A $(0.323 \pm 0.112$ fold, $P<0.0001)$ and granzyme B $(0.160 \pm 0.017$ fold, $P<0.001)$ was up regulated in IL-15/ Hsp70 group compared to IL-15 group (Fig. 4B). Meanwhile IL-15 increased the percentage of NKp44 $(92.2 \% \pm 0.30)$ (Fig. 4A-left).

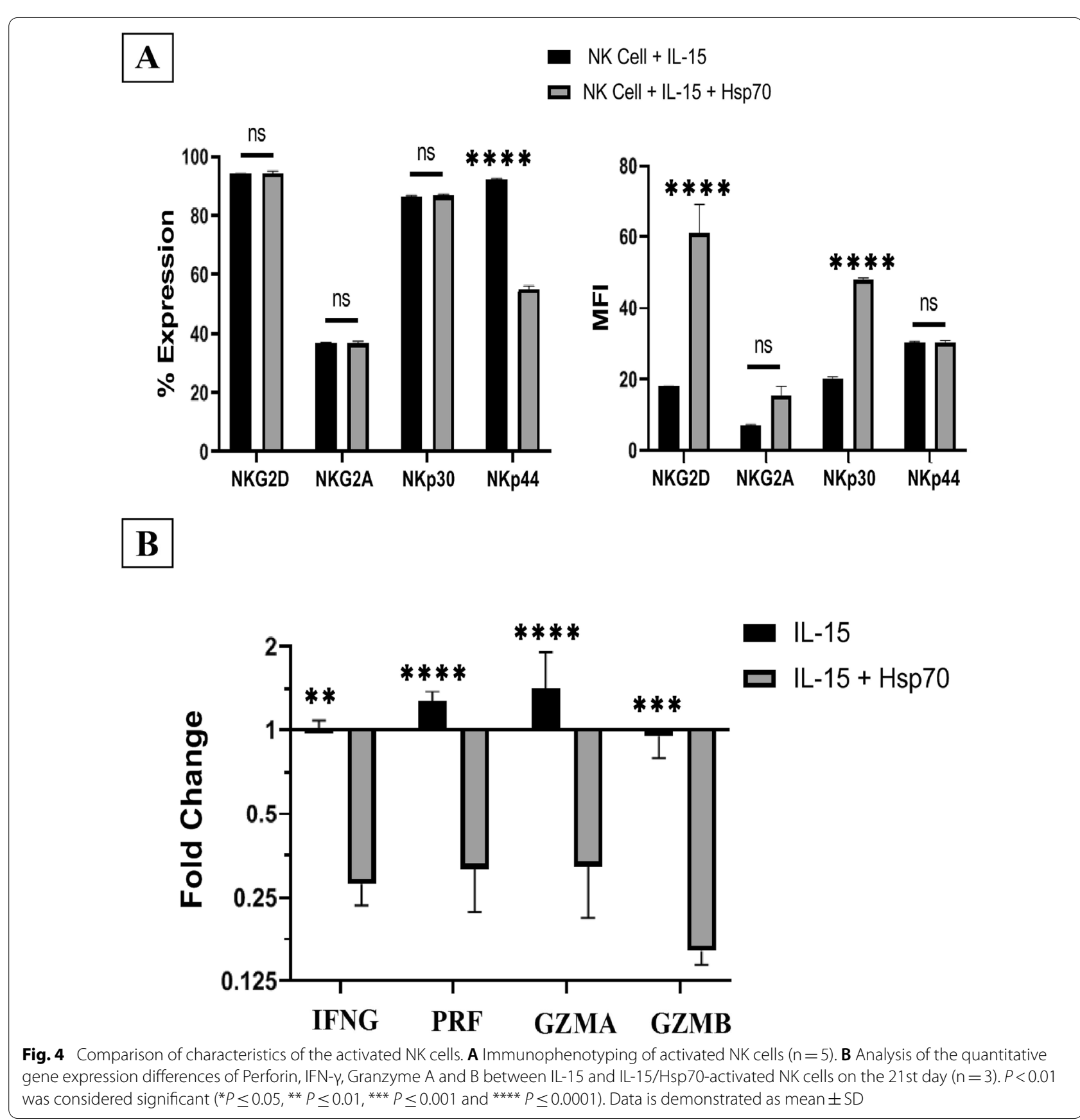




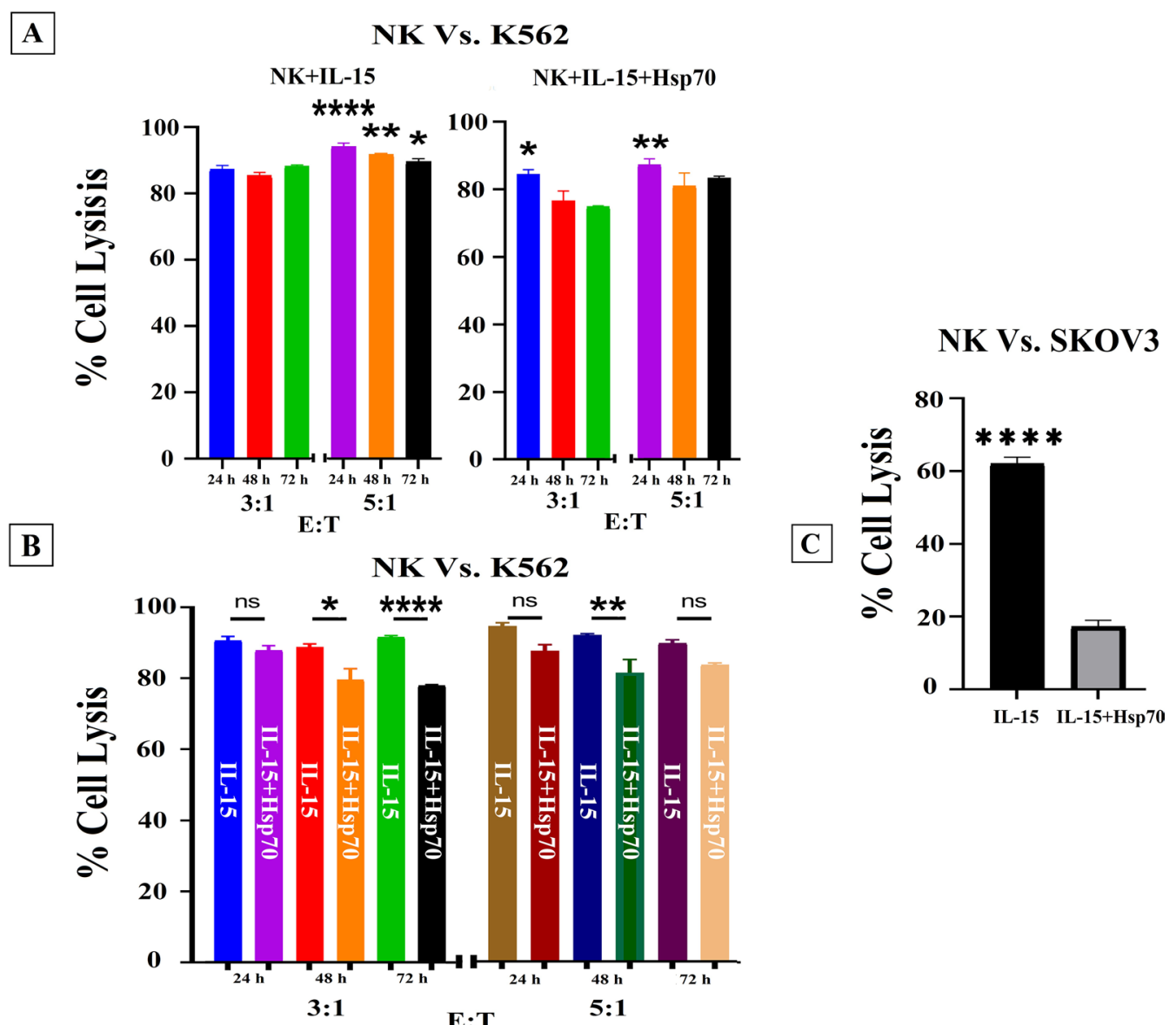

Fig. 5 Cell lysis activities of NK cells. A, Comparison of the groups at different times and different ratios against K562 cells $(n=4)$. B, Specific cell lysis analysis of IL-15 and IL-15/Hsp70-activated NK cells against K562 cells at different times and effector ratios $(n=4)$. C, Cytotoxicity assay of IL-15 and IL-15/Hsp70-activated NK cells at 3:1 ratio 48 hours after co-culture against SKOV3 cells $(n=7)$. The control cancer cells viability was about $90 \%$. Data is demonstrated as mean $\pm \mathrm{SD}, P>0.05$ which indicates no statistical significance.

The cytotoxic function of NK cells against K562 erythroleukemia cells was surveyed as the gold standard of NK cells activity assay. To perform this assay, NK cells activated by the above mentioned activating combinations, were co-cultured with K562 in 3:1 and 5:1 E:T ratios and the cell lysis potential of NK cells was analyzed in 24,48 and $72 \mathrm{~h}$ following the co-culture (Fig. 5A, B). according to the results of NK cell cytotoxicity assay in the two groups, the highest cell lysis ability was reported in 5:1 ratio and $24 \mathrm{~h}$ after co-culture with K562 tumor cells, as $94.22 \pm 1.93$ (Fig. 5A-left, B) and $87.3 \pm 3.45$ (Fig. 5A-right, B) in the groups treated with IL-15 and IL-15/Hsp70 respectively. Comparing the two treated groups with each other, the highest cell cytotoxicity was shown to be in the same ratio and time for IL-15 treated group (Fig. 5A, B).

The cytotoxic capacity of the NK cells treated with IL-15 and IL-15/Hsp70 against SKOV3 tumor cells was also assessed as a solid tumor model. According to our data, 3:1 ratio and $48 \mathrm{~h}$ led to the highest level of cell lysis in the two groups; however, the cells treated with IL-15 showed significantly higher levels of lysis $(>62 \%$, $P<0.0001)$ compared to the group treated with IL-15/ Hsp70 (>17.27\%, $P<0.001$ ) (Fig. 5C; Additional file 3: Figure S3). Finally, it was observed that the differentiated NK cells can retain their cytolytic potential and play their antitumor role for up to $72 \mathrm{~h}$ post co-culture.

\section{Discussion}

In the present study, a highly efficient cell culture protocol for ex vivo generation of functional NK cell products from UCB-HSCs through targeting RAS/MAPK, PI3K/ AKT, JAK/STAT and TGF- $\beta$ pathways was demonstrated which led to their enhanced functional activity and proliferation (Fig. 1). The cells obtained in this study have significant expansion potential of more than 600 folds (53 
folds in the expansion phase and 12 folds in the differentiation phase) (Figs. 2C, 3D) due to the use of lower doses of the molecules including $2.5 \mathrm{ng} / \mathrm{ml}$ SCF, $2.5 \mathrm{ng} / \mathrm{ml}$ TPO, $5 \mathrm{ng} / \mathrm{ml} \mathrm{rhIGF-1,} 10 \mathrm{ng} / \mathrm{ml} \mathrm{rhIL7,} 10 \mathrm{ng} / \mathrm{ml} \mathrm{rhIL21,}$ $25 \mathrm{ng} / \mathrm{ml}$ SIS3 inhibitor, $50 \mathrm{ng} / \mathrm{ml}$ rhIL15 and $20 \mu \mathrm{g} /$ $\mathrm{ml}$ rhHsp70 compared to other studies (SCF $100 \mathrm{ng} / \mathrm{ml}$ and TPO $100 \mathrm{ng} / \mathrm{ml}$ ) [28-32]. Increasing and maintaining the proliferation capacity and the cell lysis potential of NK cells were the main objectives of the present study and to achieve these goals, RAS/MAPK, PI3K/AKT, JAK/STAT and TGF-B pathways were manipulated with low doses of SFTG36/IS721/IL-15 (Fig. 1). In this study, the differentiated NK cells displayed high expression of CD56 (>95.00\%) and several activating receptors such as NKG2D (>94.00\%), NKp30 (>86.00\%) and NKp44 (>86.00\%); while the expression of NKG2A $(<36.00 \%)$ inhibitory receptor was not elevated (Figs. 3B, C; 4A).

To date, various protocols have been employed for ex vivo expansion and differentiation of NK cells from HSC sources. Despite using different combinations of cytokines with or without feeder cell lines, and the use of animal and human sera, several challenges remain still to be overcome, including the inefficiency of NK cell products [7, 9, 33-37].

It has been shown that the expanded CD34+cells could be differentiated into NK cell with an average purity of $40-60 \%$ after $5-7$ weeks of culture $[7,9,34,35]$. Many studies have reached a calculated mean expansion rate of 300-fold during the NK cell generation phase.

Several studies have reported a multiple cytokinesbased culture method for up to 6 weeks to generate the therapeutic NK cell products with high cytotoxicity function (10:1, 85\%) from CB-derived CD34+HSCs [8, 9, 35]. In the present study, a 600-fold expansion of NK cells with purity of $>90 \%$ was demonstrated after 3 weeks of culture and the NK cells differentiated from UCBCD34+ HSCs were assayed in 3:1 and 5:1 ratios so as to measure the cytotoxicity potential. These cells differentiated with a growth factor cocktail demonstrated cell lysis of $>90 \%$ against K562 tumor cells and $>60 \%$ against SKOV3 tumor cells (Fig. 5).

Generation of functionally mature killer cells is one of the fundamental problems encountered during the differentiation and activation of NK cells. In most studies, the media containing IL- 2 are used for NK cells differentiation and activation [12, 13, 20, 38]. Functionality can be induced using exogenous molecules regulating the NK cells effector factors such as IL-2, IL-15 and IL-21. They do so by increasing the expression of co-inhibitory receptors (PD-1), inhibitory receptors (NKG2A) and the upregulation of the activating receptors like NKG2D.All these changes can impair the balance of activating/inhibitory signals and consequently result in the exhaustion of NK cell functions [20, 21, 27, 39-41]. Other factors that can suppress NK cells function during differentiation and activation are suppressive cytokines such as TGF- $\beta$ which induces the downregulation of activating receptors $[12,13,20,40$, 42]. The results of this study indicated that the differentiated NK cells have low level of NKG2A inhibitory receptors which can be the reason why the cells function equally against $K 562$ cells $[12,13,42]$.

In addition, Hsp70 in the previous studies have been shown to increase the induction of NK cells. The declined cytotoxic function of Hsp70-treated NK cells against K562 and SKOV3 cells in the present study (Fig. 5; Additional file 3: Figure S3) can be explained by the dual function of Hsp70 which can also promote the cancer cells viability [27, 43-47]. Furthermore, considering the qRT-PCR results, it can be claimed that treating with Hsp70 led to a reduction in the NK cell lysis capacity compared to the other group.

A previous study has reported the positive effect of IGF-1 on human NK cell cytotoxicity and assessed the ability of endogenous miR-483-3p to regulate IGF-1 expression in UCB HSCs -derived NK cells using antimiR-483-3p to upregulate IGF-1 mRNA and protein levels. However, the exact regulatory mechanism of IGF-1 in enhancing NK cell function remains unclear. It was previously shown that IGF-1 promotes the cytotoxic function of UCB HSCs-derived NK cells [19]. But in this study, rhIGF-1 protein was used as an exogenous treat in $50 \mathrm{ng} / \mathrm{ml}$ for 14 days to induce insulin receptordependent pathways (RAS/MAPK and PI3K/AKT), and the results showed that this growth factor was effective in NK cells proliferation, maturation and activation.

In conclusion, the obtained results in the present study show that the NK cells derived via our method can induce significant lytic function against $\mathrm{K} 562(>90 \%)$ and SKOV3 (>60\%) targets in the lower ratio of effector cells compared with other studies (5:1), suggesting that the ex vivo generated UCB HSCs -derived NK cells could be suitable candidate for designing adoptive NK cell-based therapy for cancer (Fig. 5; Additional file 3: Figure S3).

This study is the first to use the combination of rhIGF-1 protein and TGF-B blockade to generate cytotoxic NK cells, and further studies are required on the other tumor cells as well as on the in vivo models. It is also essential to optimize the activation pathways and compare the cell lysis activities between $\mathrm{CB}$-derived NK cells and the peripheral blood-derived NK cells.

\section{Abbreviations}

CML: Chronic myeloid leukemia; UCB: Umbilical cord blood; E:T: Effector-totarget; HSCs: Hematopoietic stem cells; IL: Interleukin; MNCs: Mononuclear cells; NK: Natural killer. 


\section{Supplementary Information}

The online version contains supplementary material available at https://doi. org/10.1186/s12935-021-01983-z.

Additional file 1: Figure S1. CD34+ cells sorting by MACS.

Additional file 2: Figure S2.Differentiated-NK cells phenotype characterization

Additional file 3: Figure S3.Cytotoxicity of differentiated- NK cells against SKOV3 cells

Additional file 4: Table S1. Culture media in different phases of NK generation.

\section{Acknowledgements}

The authors would like to acknowledge Brigand University of Medical Sciences, The Cancer Research Center of Cancer Institute of Iran, Royan Stem Cell Technology Co., and Royan lotus charity fund for funding this project.

\section{Authors' contributions}

AS: conception and design, performed experiments, data analysis and interpretation, collection and/or assembly of data, manuscript writing, discussed the results and commented on the manuscript. MY: experiments planning, interpretation, discussed the results and commented on the manuscript. MF: experiments planning, interpretation, discussed the results and commented on the manuscript. MN: experiments planning, interpretation, discussed the results and commented on the manuscript. GAS: conception and design, interpretation, financial support, provision of study material, discussed the results and commented on the manuscript, final approval of manuscript, Administrative support and supervision. ME: conception and design, interpretation, financial support, provision of study material, discussed the results and commented on the manuscript, final approval of manuscript, administrative support and supervision. All authors read and approved the final manuscript.

\section{Funding}

This work was supported by Birjand University of Medical Sciences (as Ph.D. thesis with ID No: 455421), Cancer Research Center of Cancer Institute of Iran (Shams cancer charity, Grant No: 37312-202-01-97) and Royan Stem Cell Technology Co., (Grant No. RSCT96030201) and Royan lotus charity fund.

\section{Availability of data and materials}

The datasets used and analyzed during the current study are available from the corresponding author on reasonable request.

\section{Declarations}

\section{Ethics approval and consent to participate}

All CB samples were obtained with prior consent and ethical committee approval from the Cord Blood Bank, Royan Stem Cell Technology Co., with the following ethical codes: IR.BUMS.REC.1396.321 and IR.ACECR.ROYAN. REC.1397.171.

\section{Consent for publication}

Not applicable.

\section{Competing interests}

The authors declare that they have no competing interests.

\section{Author details}

'Department of Molecular Medicine, Genomic Research Center, Birjand University of Medical Sciences, Birjand, Iran. ${ }^{2}$ Cellular \& Molecular Research Center, Birjand University of Medical Sciences, Birjand, Iran. ${ }^{3}$ Department of Stem Cells and Developmental Biology, Cell Science Research Center, Royan Institute for Stem Cell Biology and Technology, ACECR, Tehran, Iran. ${ }^{4}$ Stem Cell Transplantation and Regenerative Medicine, Department of Pediatrics, Stanford University School of Medicine, Palo Alto, CA, USA. ${ }^{5}$ R\&D Department, Royan Stem Cell Technology Co, Tehran, Iran.
Received: 24 October 2020 Accepted: 13 May 2021

Published online: 07 June 2021

\section{References}

1. Lim O, Jung MY, Hwang YK, Shin EC. Present and future of allogeneic natural killer cell therapy. Front Immunol. 2015;6:286.

2. Souza-Fonseca-Guimaraes F, Cursons J, Huntington ND. The emergence of natural killer cells as a major target in cancer immunotherapy. Trends Immunol. 2019:40(2):142-58.

3. Farag SS, Caligiuri MA. Human natural killer cell development and biology. Blood Rev. 2006;20(3):123-37.

4. Gardiner CM. NK cell metabolism. J Leukoc Biol. 2019;105(6):1235-42.

5. Klingemann $\mathrm{H}$. Challenges of cancer therapy with natural killer cells. Cytotherapy. 2015;17(3):245-9.

6. Mehta RS, Shpall EJ, Rezvani K. Cord blood as a source of natural killer cells. Front Med. 2015;2:93.

7. Mu YX, Zhao YX, Li BY, Bao HJ, Jiang H, Qi XL, et al. A simple method for in vitro preparation of natural killer cells from cord blood. BMC Biotechnol. 2019;19(1):80

8. Pinho MJ, Punzel M, Sousa M, Barros A. Ex vivo differentiation of natural killer cells from human umbilical cord blood CD34+ progenitor cells. Cell Commun Adhes. 2011:18(3):45-55.

9. Spanholtz J, Preijers F, Tordoir M, Trilsbeek C, Paardekooper J, de Witte T, et al. Clinical-grade generation of active NK cells from cord blood hematopoietic progenitor cells for immunotherapy using a closed-system culture process. PLoS ONE. 2011;6(6):e20740.

10. Briard D, Brouty-Boye D, Azzarone B, Jasmin C. Fibroblasts from human spleen regulate NK cell differentiation from blood CD34(+) progenitors via cell surface IL-15. J Immunol. 2002;168(9):4326-32.

11. Borrego F, Ulbrecht M, Weiss EH, Coligan JE, Brooks AG. Recognition of human histocompatibility leukocyte antigen (HLA)-E complexed with HLA class I signal sequence-derived peptides by CD94/NKG2 confers protection from natural killer cell-mediated lysis. J Exp Med. 1998;187(5):813-8.

12. Bi J, Tian Z. NK Cell Exhaustion. Front Immunol. 2017:8:760.

13. Judge SJ, Murphy WJ, Canter RJ. Characterizing the dysfunctional NK cell: assessing the clinical relevance of exhaustion, anergy, and senescence. Front Cell Infect Microbiol. 2020;10:49.

14. Vely F, Vivier E. Natural killer cell receptor signaling pathway. Sci STKE. 2005;2005(292):cm6.

15. Chester C, Fritsch K, Kohrt HE. Natural killer cell immunomodulation: targeting activating, inhibitory, and co-stimulatory receptor signaling for cancer immunotherapy. Front Immunol. 2015;6:601.

16. Chan CJ, Smyth MJ, Martinet L. Molecular mechanisms of natural killer cell activation in response to cellular stress. Cell Death Differ. 2014:21(1):5-14.

17. Vivier E, Nunes JA, Vely F. Natural killer cell signaling pathways. Science. 2004:306(5701):1517-9.

18. Watzl C, Long EO. Signal transduction during activation and inhibition of natural killer cells. Curr Protoc Immunol. 2010;90:11-9.

19. Ni F, Sun R, Fu B, Wang F, Guo C, Tian Z, et al. IGF-1 promotes the development and cytotoxic activity of human NK cells. Nat Commun. 2013;4:1479.

20. Seo H, Jeon I, Kim BS, Park M, Bae EA, Song B, et al. IL-21-mediated reversal of NK cell exhaustion facilitates anti-tumour immunity in MHC class I-deficient tumours. Nat Commun. 2017;8:15776.

21. Skak K, Frederiksen KS, Lundsgaard D. Interleukin-21 activates human natural killer cells and modulates their surface receptor expression. Immunology. 2008;123(4):575-83.

22. Jinnin M, Ihn H, Tamaki K. Characterization of SIS3, a novel specific inhibitor of Smad3, and its effect on transforming growth factor-beta1-induced extracellular matrix expression. Mol Pharmacol. 2006;69(2):597-607.

23. Tang PM, Zhou S, Meng XM, Wang QM, Li CJ, Lian GY, et al. Smad3 promotes cancer progression by inhibiting E4BP4-mediated NK cell development. Nat Commun. 2017;8:14677. 
24. Wang QM, Tang PM, Lian GY, Li C, Li J, Huang XR, et al. Enhanced cancer immunotherapy with Smad3-silenced NK-92 cells. Cancer Immunol Res. 2018:6(8):965-77.

25. Michaud A, Dardari R, Charrier E, Cordeiro P, Herblot S, Duval M. IL-7 enhances survival of human CD56bright NK cells. J Immunother. 2010;33(4):382-90.

26. Wu Y, Tian Z, Wei H. Developmental and functional control of natural killer cells by cytokines. Front Immunol. 2017;8:930.

27. Sharifzad F, Mardpour S, Mardpour S, Fakharian E, Taghikhani A, Sharifzad A, et al. HSP70/LL-2 treated NK cells effectively cross the blood brain barrier and target tumor cells in a rat model of induced glioblastoma multiforme (GBM). Int J Mol Sci. 2020;21(7):2263.

28. Chotinantakul K, Prasajak P, Leeanansaksiri W. Wnt1 Accelerates an Ex Vivo Expansion of Human Cord Blood CD34(+)CD38(-) Cells. Stem Cells Int. 2013;2013:909812.

29. Denning-Kendall P, Singha S, Bradley B, Hows J. Cytokine expansion culture of cord blood CD34+ cells induces marked and sustained changes in adhesion receptor and CXCR4 expressions. Stem Cells. 2003;21(1):61-70.

30. Herrera C, Sanchez J, Torres A, Bellido C, Rueda A, Alvarez MA. Early-acting cytokine-driven ex vivo expansion of mobilized peripheral blood CD34+ cells generates post-mitotic offspring with preserved engraftment ability in non-obese diabetic/severe combined immunodeficient mice. $\mathrm{Br} J$ Haematol. 2001;114(4):920-30.

31. Mourcin F, Grenier N, Mayol JF, Lataillade JJ, Sotto JJ, Herodin F, et al. Mesenchymal stem cells support expansion of in vitro irradiated CD34(+) cells in the presence of SCF, FLT3 ligand, TPO and IL3: potential application to autologous cell therapy in accidentally irradiated victims. Radiat Res. 2005;164(1):1-9.

32. Zhang $Y$, Shen B, Guan $X$, Qin M, Ren Z, Ma Y, et al. Safety and efficacy of ex vivo expanded CD34(+) stem cells in murine and primate models. Stem Cell Res Ther. 2019;10(1):173.

33. Dezell SA, Ahn YO, Spanholtz J, Wang H, Weeres M, Jackson S, et al. Natural killer cell differentiation from hematopoietic stem cells: a comparative analysis of heparin- and stromal cell-supported methods. Biol Blood Marrow Transpl. 2012;18(4):536-45.

34. Kao IT, Yao CL, Kong ZL, Wu ML, Chuang TL, Hwang SM. Generation of natural killer cells from serum-free, expanded human umbilical cord blood CD34+ cells. Stem Cells Dev. 2007;16(6):1043-51.

35. Spanholtz J, Tordoir M, Eissens D, Preijers F, van der Meer A, Joosten I, et al. High log-scale expansion of functional human natural killer cells from umbilical cord blood CD34-positive cells for adoptive cancer immunotherapy. PLoS ONE. 2010;5(2):e9221.

36. Domogala A, Blundell M, Thrasher A, Lowdell MW, Madrigal JA, Saudemont A. Natural killer cells differentiated in vitro from cord blood CD34(+) cells are more advantageous for use as an immunotherapy than peripheral blood and cord blood natural killer cells. Cytotherapy. 2017;19(6):710-20.
37. Hosseini E, Ghasemzadeh M, Kamalizad M, Schwarer AP. Ex vivo expansion of CD3(depleted) cord blood-MNCs in the presence of bone marrow stromal cells; an appropriate strategy to provide functional NK cells applicable for cellular therapy. Stem Cell Res. 2017;19:148-55.

38. Alvarez M, Simonetta F, Baker J, Pierini A, Wenokur AS, Morrison AR, et al. Regulation of murine NK cell exhaustion through the activation of the DNA damage repair pathway. JCl Insight. 2019:4:5.

39. Gasteiger G, Hemmers S, Firth MA, Le Floc'h A, Huse M, Sun JC, et al. IL2-dependent tuning of NK cell sensitivity for target cells is controlled by regulatory T cells. J Exp Med. 2013;210(6):1167-78.

40. Huenecke S, Zimmermann SY, Kloess S, Esser R, Brinkmann A, Tramsen $L$, et al. IL-2-driven regulation of NK cell receptors with regard to the distribution of CD16+ and CD16 - subpopulations and in vivo influence after haploidentical NK cell infusion. J Immunother. 2010;33(2):200-10.

41. Miller JS, Tessmer-Tuck J, Blake N, Lund J, Scott A, Blazar BR, et al. Endogenous IL-2 production by natural killer cells maintains cytotoxic and proliferative capacity following retroviral-mediated gene transfer. Exp Hematol. 1997;25(11):1140-8.

42. Zhang C, Wang XM, Li SR, Twelkmeyer T, Wang WH, Zhang SY, et al. NKG2A is a NK cell exhaustion checkpoint for HCV persistence. Nat Commun. 2019;10(1):1507.

43. Gyrd-Hansen M, Nylandsted J, Jaattela M. Heat shock protein 70 promotes cancer cell viability by safeguarding lysosomal integrity. Cell Cycle. 2004;3(12):1484-5.

44. Multhoff G. Activation of natural killer cells by heat shock protein 70. Int J Hyperth. 2009;25(3):169-75.

45. Qiao Y, Liu B, Li Z. Activation of NK cells by extracellular heat shock protein 70 through induction of NKG2D ligands on dendritic cells. Cancer Immun. 2008:8:12.

46. Specht HM, Ahrens N, Blankenstein C, Duell T, Fietkau R, Gaipl US, et al. Heat shock protein 70 (Hsp70) peptide activated natural killer (NK) cells for the treatment of patients with non-small cell lung cancer (NSCLC) after radiochemotherapy (RCTx) - from preclinical studies to a clinical phase II trial. Front Immunol. 2015;6:162.

47. Zorzi E, Bonvini P. Inducible Hsp70 in the regulation of cancer cell survival: analysis of chaperone induction, expression and activity. Cancers. 2011;3(4):3921-56.

\section{Publisher's Note}

Springer Nature remains neutral with regard to jurisdictional claims in published maps and institutional affiliations.
Ready to submit your research? Choose BMC and benefit from:

- fast, convenient online submission

- thorough peer review by experienced researchers in your field

- rapid publication on acceptance

- support for research data, including large and complex data types

- gold Open Access which fosters wider collaboration and increased citations

- maximum visibility for your research: over $100 \mathrm{M}$ website views per year

At BMC, research is always in progress.

Learn more biomedcentral.com/submissions 